\title{
Government Policy in the Natural Resource Management of Local Community
}

\author{
Revency Vania Rugebregt ${ }^{1}$, Abrar Saleng ${ }^{2}$, Farida Patittingi ${ }^{3}$ \\ ${ }^{I}$ Faculty of Law, Pattimura University \\ Jl. Ir. M. Putuhena, Kampus Poka, Ambon, 97233, Maluku, Indonesia \\ Tel./Fax: +62-911-322627 E-mail: revency_rugebregt@yahoo.com \\ ${ }^{2}$ Faculty of Law, Hasanuddin University \\ Jl. Perinstis Kemerdekaan KM. 10, Tamalanrea, Makassar, Indonesia \\ Tel./Fax: +62-411-587219 E-mail: abrarsaleng@yahoo.com \\ ${ }^{3}$ Faculty of Law, Hasanuddin University \\ Jl. Perinstis Kemerdekaan KM. 10, Tamalanrea, Makassar, Indonesia \\ Tel./Fax:+62-411-587219E-mail: patittingi@yahoo.co.id \\ Submitted: Dec 19, 2015; Reviewed: Jan 30, 2016; Accepted: Feb 12, 2016
}

\begin{abstract}
Natural resource management is an important thing that should be done by the community for survival. Consciously of many ways in the management of natural resources has resulted in environmental damage, coupled with government policies that give permission without good supervision to entrepreneurs or private individuals in natural resource management adds a long list of environmental damage. In the last three decades, governments tend to ignore the phenomenon of legal pluralism in the legal development policy, preparation of legal instruments, as well as the implementation of the law through political neglect of the fact legal pluralism. So the product of legislation, especially those that set natural resource management, normatively ignore and displace the rights of indigenous peoples and local over control, management, and utilization of natural resources. Moreover, with deprivation of the rights of indigenous peoples' customary rights and the implementation of development without taking into consideration the pattern of spatial planning, more and enlarge the conflict between the government and society.
\end{abstract}

Keywords: Customary Law; Indigenous Peoples; Natural Resource

DOI: http://dx.doi.org/10.20956/halrev.v1n1.219

\section{INTRODUCTION}

Maluku province as one of the oldest Province in Indonesia is an archipelago province which a rich biological sources in sea and on land which is the wealth of the region used for survival. In most of the Maluku region, there are still groups of indigenous or customary law community unit which generally still apply custom or customary law in their life, especially in the Management of Natural resources and the coastal ocean. In implementing the existing traditions, natural resources must be used wisely to ensure their continuity occurs. 
Indonesia is the largest archipelagic state in the world that consists of about 17,500 islands with an area of sea about 5.8 million $\mathrm{km}^{2}$ and stretches along the lines of $81,000 \mathrm{~km}$. Most of the islands are small islands bestowed with abundance natural resources and environmental services offering huge potentials for economic development. ${ }^{1}$ Unfortunately, for decades, coastal areas and their potentials were rather ignored, because the orientation of development in Indonesia always put emphasis on the development of big islands, especially Java. After the reform era, since 1998, the management of coastal areas has started to be developed quite seriously. Unfortunately, the government's attention was not accompanied by a bottom-up approach that involves a population or community living in marine and coastal areas.

Various policies from both the central and local governments have marginalized people who have rights over the areas. For example, permits granted by the government to individuals or corporations to manage the coastal ocean, has often resulted in unfavorable situations for the local people. In many cases, these people lost their access to coastal areas and can no longer able to conduct economic activities in these areas once a permit is granted.

\section{ANALYSIS AND DISCUSSION Indigenous People in Management Con- servation}

The role of customary institutions in natural resource management in Indonesia related to

Department of Marine and Fisheries, Republic of Indonesia. (2001). Pedoman Umum Pengelolaan Pulaupulau Kecil yang Berkelanjutan dan Berbasis Masyarakat. Jakarta: Department of Marine and Fisheries, Republic of Indonesia, p. 5. coastal and marine ecosystem, such as Sasi. Lucky Adrianto pointed that all components of fisheries management, perhaps in unwritten form, could be observer in the practices of costumary management systems studied. For example, the boundries of the resource are clearly demarcated; right holders are clearly identified; rules for regulating resource use; system for monitoring use; and for sanctioning of violations are in place; and there is a fisheries management authority (vested in the customary institution and its chief).

The evolution from centralization to decentralization was re-started during the Reform Era, with the enactment by the Law Number 22 of 1999 concerning the Local Autonomy Law, which was revised with law Number 32 of 2004 . The chance has been opened for a shift in the fisheries governance system, a shift of regime from a top-down to a bottom-up approach, which encourages more participation of the communities through the revitalization of community-based management system. The management system has to consider local custom, local customary practices as well as community involvement. Thus, a frame for the implementation of management already exist, but implementation needs stronger political support, with ecosystem and sustainable management principles as the bases. Historically and philosophically, tradition and customary law are considered the manifestation of a nation's soul from generation to generation ${ }^{2}$

\footnotetext{
Luky Adrianto. "Session: Customary Institutions and Fisheries and Coastal Area Management." In KG. Kumar (eds.). (2009). The Indonesia Workshop Report, Customary Institution in Indonesia: Do they have a role in Fishery and Coastal Area Menagement? Internation-
} 
Sasi as tradition for local community still exist until now. With kewang as law enforcement of sasi rules, this tradition continues to thrive and survive in protecting the environment. Change of government system and the enactment a variety of products with regard to natural resources, both on land and at sea, does not alter the structure, the duties and authority of kewang. Kewang remained consistent implementing measures to protect natural resources, although the state constitution does not agree with it.

Example case, when the problem occurred in 1997 between the kewang Haruku village, which representing people at Haruku Village against PT. Aneka Tambang when they have permission from central government to exploitation gold resources in the petuanan $^{3}$ Haruku village. On the persistence kewang fight rejection the activity of PT. Aneka Tambang at the regional, national and international levels, then at the end PT. Aneka Tambang out of the petuanan Haruku village.

Another case story, in 2007 when one of the Consultants Company who received permission from the central government and local government conduct a study of sources - geothermal resources in the petuanan Haruku village. Rejection by the kewang Haruku village published and advocated at the local and central government, have an impact on the cessation of the study. Not because the Kewang refused exploitation and research, but the activity is done without good plan-

al Collective in Support of Fishworkers. Lombok, 2- 5 Agustus 2009, pg. 19-21.

In Indonesian called ulayat, but for Maluku called petuanan. ning and not environmentally and damaging places around the location of the activities.

\section{Government Policies in Marine and Coastal Area Management}

Damage on natural resources has the potential to severely affect communities that are highly dependent on the resources. In this regard, coastal communities, which heavily depend on coastal areas and the sea to support their life, will suffer significant losses if these areas are damaged. For the coastal communities, coastal areas and the sea are the sources of life. Through the interaction and adaptation taking place for a very long time, customary coastal communities have created and developed values, patterns of life, institutions, and laws reflecting the harmony with the conditions and availability of natural resources.

In many places in Maluku, customary rules on marine management have existed long before the existence of Indonesia. These traditional rules have indicated the traditional way of thinking in recognizing and respecting the importance of sustainability in the management of marine resources for local communities. For many years the communities have practiced and developed their cultural traditions and customs related to the management of marine resources, leading to various traditional customs that are rich in diversity and dynamic in nature.

Natural resources, including marine natural resources, are the assets of the national economy, which shall be managed pursuant to the Article 33 paragraph (3) of the 1945 Constitution, stating that 'Soil and water and natural wealth contained therein 
shall be controlled by the state and used for the welfare of the people to the utmost'. According to Hatta, one of the founding fathers of Indonesia, the phrase 'controlled by the State' does not mean that the State itself functions as an entrepreneur. Instead, the phrase should refer to the state's authority to formulate economic regulations related to natural resources, and at the same time to prevent the exploitation of certain parts of society by the capital owners. ${ }^{4}$ In principle, the control of the State is the authority of the state to manage natural resources for the greatest benefits of the people, executed by establishing laws that protect the rights of the people.

In establishing such laws, one important aspect is the recognition of the customary law community, and their community-based rights. In this regard, Darmansyah ${ }^{5}$ praises the enactment of the Regional Government Act of 1999 because the act promotes regional autonomy and decentralization. Under the concept of regional autonomy, decentralized authorities should be based on pluralism of the regions so as to lead not only to the formation of autonomous provinces or regencies/cities, but also to the recognition of customary law community as the genuine autonomous region. Certainly, each customary law community has its own autonomous structures, functions, and authorities.

Regional autonomy and the recognition of indigenous people should certainly affect the authorities in the management of

\footnotetext{
Mohammad Hatta. (1977). Pasal 33 Undang-Undang Dasar 1945. Jakarta: Mutiara, p. 28.

Darmansyah. (2003). Optimalisasi Pelaksanaan Otonomi Daerah, dalam Otonomi Daerah; Eevaluasi dan Proyeksi, Jakarta: Yayasan Harkat BangsaPartenrship.p.193.
}

marine and coastal areas. In this regard, the authorities should be vested not only in the central, provincial, or local governments, but also in the customary law community.

The implementation of various laws and regulations related to coastal and marine management is often in conflict with customary law that also regulates the management and utilization of natural resources in coastal areas and the sea. This conflict occurs despite the adat communities and their embedded rights have been constitutionally recognized in the Article 18B paragraph (2) of the 1945 Constitution of the Republic of Indonesia, which states that:

"The State recognizes and respects traditional communities along with their traditional customary rights as long as these remain in existence and are in accordance with the societal development and the principles of the Unitary State of the Republic of Indonesia, and shall be regulated by law."

After the reform era, starting from the fall of the Suharto's New Order regime in 1998, the central government is faced with strong political pressures to decentralized most of authorities related to the management of natural resources. These political pressures led to the enactment of Act No. 22 of 1999, later amended by Act No. 32 of 2004, concerning regional government that formalize regional autonomy and decentralization in Indonesia. Under the Regional Government Act, regional government has self-governing authorities in many aspects of governance, including those related to the management of natural resources. Theoretically, such autonomous authorities should 
lead to the formation of laws or institutions that express the special needs and characteristics of each region.

In Syafa'at's point of view, by the enactment of the regional government act, the central government attempts to offer a paradigmatic alternative concerning the relationship between the central government and local government, as well as between government and the adat communities. The regional government act has also shifted the management of coastal and marine resources, from a centralized into a more decentralized management. Such a paradigm shift represents autonomy-based management, by which local government, especially the regency and city, has greater authority in fishery management.

In reality, however, many regulations are sectoral in nature, in that they are actually directed to address some specific issues, which indirectly correspond to coastal and marine areas. This situation has, in many cases, led to overlapping authorities and regulations. Furthermore, such sectoral regulations have also the potentials to contravene with the existing and well-functioning customary laws (the adat laws) that also address coastal and marine management.

The largest portion of Indonesia's territory consists of marine area, and a large number of adat communities occupy some of Indonesia's coastal areas. These communities have traditionally controlled coastal and marine areas according to customarybased sea tenures referred to as hak adat kelautan. The real control over costal and marine areas by these communities is closely related to the relationship between the com- munities and the areas and resources within, which has been inherited from the communities' ancestors. The areas under the control of the adat communities are characterized by the distinct authorities of the communities. In this context, authority means legitimate power owned by an individual or group of individuals to rule, govern, make decisions, enforce rules, or execute mandates.

In many part of Indonesia, the adat communities have the authority to manage surrounding natural resources based on genealogical rights, inherited from their ancestors. Such rights exist even before the existence of Indonesia, and hence, cannot be separated from the existence of the communities.

According to Act No. 32 of 2004, the regency or city has the authority to manage marine resources up to 4 miles from the shoreline, and the provincial government has such an authority from 4 miles up to 12 miles from the shoreline. Such an arrangement might in reality contravene the adat communities' rights in managing marine resources, since in many cases the communities have their own territorial rights according to the communities' adat law. ${ }^{6}$

Conflicts might arise if these communities' rights are ignored in the government policies. These conflicts might eventually

${ }^{6}$ Revency Vania Rugebregt. (2011). Revitalization of the Kewang Institute In The Sustainable Management Of Marine And Coastal Natural Resources in Maluku Province, Present at the International Seminar "Environmental, Health and Safety Risks in Globalizing World, 2011, June 27 to 28, Denpasar Bali, Indonesia, Faculty of Law, University of Udayana, Bali in cooperation with Mundo, Maastrichts University, Metro, The Institute for Transnational Legal Research for (in Dutch: Instituut voor Europees Maastrichts Transnationaal Rechhtswetenschappelijk Ondezoek), Maastricht University and the Faculty of Law, Universita Gajah Mada, Yogyakarta. 
impair the effectiveness of the sustainable development and management of marine resources. Hence, the recognition of the adat communities' rights plays a significant role to ensure sustainable management of marine resources.

The adat communities' rights in the management of coastal and marine resources are based on the so-called ulayat laut, i.e. sea tenure. In Maluku, this sea tenure is called petuanan laut. In practice, the petuanan laut represents a system where individuals or social groups take benefits from marine resources by setting up certain level of exploitation, which is often guided by local wisdom so as to prevent over exploitation. ${ }^{7}$

A study of Hendrik Hattu shows that in general all negeris in Ambon and Laese Islands recognize the existence of petuanan laut as a concept of property, indicated by the following boundaries:

a. Boundaries between adjacent petuanan laut (sea tenures)

In general, the boundaries are established by drawing an imaginary line from shores of each negeri until the line touches the boundary between shallow water (in local term referred to as the air putih, white water) and deep water (in local term referred to as the air biru, blue water).

b. Boundaries between a sea tenure and high seas

The boundaries represent the boundary between shallow water and deep water. In this sense, deep water is considered high seas that can be accessed and

A. Wahyono. (2000). Hak Ulayat Laut di Kawasan Timur Indonesia, Jakarta: Media Pressindo. p.54. utilized by any body.

These boundaries exist in the petuanan laut of almost all adat communities in Maluku. They are established and determined through the structure of each adat community. More importantly, the adat community has usually set up its own authority and law to govern how the member of the community can utilize the resources within the territory of the community. In Maluku, such authority and law are represented in the form of kewang and sasi.

The sasi is 'a ban on the use of specific piece of land tree or sea during a certain period', ${ }^{8}$ or a prohibition on harvesting specified domesticated and non-domesticated land, tree and sea resources. ${ }^{9}$ The kewang is an adat institution which is charged with the management of society's natural and economic resource. It also supervises the implementation of adat rules and public order. ${ }^{10}$ The kewang has, to some extent, functions similar to the police, with specific purpose in ensuring the protection of the environment.

Unfortunately, as it has been discussed earlier, in many part of Indonesia, traditional institutions that may help manage and protect the environment, like kewang and sasi,

\footnotetext{
Benda-Beckmann and Brouwer. (1992). Changing Indigenous Environmental law in The Central Molluccas: Communal Regulation and Privatization of Sasi', Paper Presented to the Congress of the Commission on Folks Law and Legal Pluralism at Victoria University, Wellington.

9 F.R. Ellen. (1978). Naulu Settlement and Ecology: an Approach to the Environmental Relation of and Eastern Indonesia Community, Verhandelingen KITLV No. 83, The Hague: M. Nijhoff.

10 Eliza Kissya. (1995). Kewang Negeri Haruku dan Keberadaanya', presented at Workshop and Seminar 'Lembaga Adat Indonesia: Apakah mereka memiliki Peran Dalam Pengelolaan Sumberdaya Perikanan dan Wilayah Pesisir?', ICSF, Dinas Kelautan dan Perikanan, Lombok, Indonesia, 2-5 August, Nusa Tenggara Barat, p.22.
} 
are in the brink of extinction due to political ignorance of legal pluralism practiced for more than three decades. In this regard, various legislative products or government policies, especially those related to the management of natural resources, have tended to ignore and eliminate the rights of indigenous people to control, manage, and utilize natural resources. ${ }^{11}$

Decentralization and regional autonomy that have extensively promoted since the political reform of 1998, do not necessarily lead to better environmental protection and recognition of the adat communities' rights. In fact, when one carefully examines recent legislative products or policies related to natural resources, one soon finds a tendency towards more centralized, exploitative or use-oriented, capital-oriented, sectoral heavy, and not transparent laws. One can also easily find many examples of laws that lack public participation and ignore the rights of the adat communities. In this sense, one may conclude that many laws or policies issued by both central and local governments have been the source of environmental degradation and the marginalization of the adat communities in many parts of Indonesia.

It must be stressed once again that, the traditional wisdom like these sasi rules in fact have existed for a long time, so that the rules which are here written down, in essence only reiterate the adat rules which has been handed down from the ancestors of the village. Nevertheless, as is seen clearly in the rules of river sasi, a number of additional regulation have been

$\overline{11}$ R. Topatimasang. (2004). Orang-Orang Kalah - Kisah Penyingkiran Masyarakat Adat Kepulauan Maluku. Yogyakarta: Insist Press. formulated (for example, the prohibition on the operation of motor boats - with engine running - on the river) to anticipate modern day developments.

Similarly, the rules regulating the size of cash fine imposed for violations also have been adjusted to represent economic development. An example of an addition to the river sasi is the prohibition on the use of a certain of fine meshed factory made net (karoro) which was type formerly unknown and has only appeared in the last few years. Experience has shown that this type of fishing equipment is very damaging because it is capable of catching all fish regardless of size. (It resembles the "pukat harimau" or large trawling nets).

The same is true of the prohibition in the village sasi of tree climbing by women, which has been renewed. This prohibition was changed to allow women to climb tress as long as they use appropriate clothing, a.o., because appropriate clothing is now also available (such as long pants) to be worn by women. All this indicates that sasi is not a collection of rigid regulations. It continues to be dynamic and responsive the changing times, as long as the essence of its spirit, soul or life (i.e., the principle of conservation and balance in man's life with other men and in his relationship with the surrounding natural world) does not change and is maintained.

\section{CONCLUSION}

Expected future management of natural resources carried out in accordance with regional characteristics with bio-region approach and socio-cultural conditions of local communities; Acknowledging the 
existence of access and rights of indigenous peoples and local wisdom in the mastery and utilization of natural resources; Recognizing fully and accommodate proportionate legal pluralism in a society grow and develop into a product of state law.

To protect the marine tenure in future, the key word that should be adhered to is the integrated management and sustainability. Thus it is necessary for legal tools that can give legitimacy to the existence, structure, powers and functions of traditional governance institutions, including kewang on the island of Ambon and Lease Islands, which is collectively responsible for preserving the coastal environment for the welfare of society at large.

\section{BIBLIOGRAPHY}

A. Wahyono. (2000). Hak Ulayat Laut di Kawasan Timur Indonesia, Jakarta: Media Pressindo.

Benda-Beckmann and Brouwer. (1992). Changing Indigenous Environmental law in The Central Molluccas: Communal Regulation and Privatization of Sasi', Paper Presented to the Congress of the Commission on Folks Law and Legal Pluralism at Victoria University, Wellington.

Darmansyah. (2003). Optimalisasi Pelaksanaan Otonomi Daerah, dalam Otonomi Daerah; Eevaluasi dan Proyeksi, Jakarta: Yayasan Harkat BangsaPartenrship.

Department of Marine and Fisheries, Republic of Indonesia. (2001). Pedoman Umum Pengelolaan Pulau-pulau Kecil yang Berkelanjutan dan Berbasis
Masyarakat. Jakarta: Department of Marine and Fisheries, Republic of Indonesia.

Eliza Kissya. (1995). Kewang Negeri Haruku dan Keberadaanya', presented at Workshop and National Seminar entitled, 'Lembaga Adat Indonesia: Apakah mereka memiliki Peran Dalam Pengelolaan Sumberdaya Perikanan dan Wilayah Pesisir?', ICSF, Lombok, Indonesia, 2-5 August.

F.R. Ellen. (1978). Naulu Settlement and Ecology: an Approach to the Environmental Relation of and Eastern Indonesia Community, Verhandelingen KITLV No. 83, The Hague: M. Nijhoff.

KG. Kumar (eds.). (2009). The Indonesia Workshop Report, Customary Institution in Indonesia: Do they have a role in Fishery and Coastal Area Menagement? International Collective in Support of Fishworkers. Lombok, 2- 5 Agustus 2009.

Mohammad Hatta. (1977). Pasal 33 UndangUndang Dasar 1945. Jakarta: Mutiara. R. Topatimasang. (2004). Orang-Orang Kalah - Kisah Penyingkiran Masyarakat Adat Kepulauan Maluku. Yogyakarta: Insist Press.

Revency Vania Rugebregt. (2011). Revitalization of the Kewang Institute in the Sustainable Management of Marine and Coastal Natural Resources in Maluku Province. Present at the International Seminar "Environmental, Health and Safety Risks in Globalizing World, 2011, June 27-28, Denpasar Bali, Indonesia. 